Columbia Business School
Center on Japanese Economy and Business

CENTER ON JAPANESE ECONOMY AND BUSINESS

日本经湇经営研究所

Working Paper Series

April 2015, No. 342

\title{
Selective Disclosure: The Case of Nikkei Preview Articles
}

William Goetzmann, Yasushi Hamao, and Hidenori Takahashi 


\title{
Selective Disclosure: The Case of Nikkei Preview Articles*
}

\author{
This version: February 11, 2015 \\ William N. Goetzmann, Yale School of Management and NBER \\ Yasushi Hamao, University of Southern California \\ Hidenori Takahashi, Kobe University
}

\begin{abstract}
Nihon Keizai Shinbun (Nikkei for short) is a leading Japanese daily newspaper specializing in economy and business. It is also the largest vendor of Japanese financial and economic databases. During earnings announcement season, the Nikkei morning edition often publishes "preview" articles that are about companies' sales and earnings. However, these pre-date the actual company announcements, and forecast more accurately the actual results than the existing forecasts, making the Nikkei forecasts value-relevant information. We identify 2,899 preview articles in the newspaper from 2000 to 2010 . We examine the circumstances under which these preview articles are written and the impact they have on the market. Our (preliminary) findings show that the market reacts to the information even before the preview articles are printed, suggesting some leakage of the information to market participants. The costs and benefits (or incentives) for companies, Nikkei, and investors are investigated using changes in returns and information content around the events.
\end{abstract}

\footnotetext{
* We thank lunch seminar participants at University of Southern California. We are grateful to Kenneth Ahern, Harry DeAngelo, Gerard Hoberg, Arthur Korteweg, Kevin Murphy, Marina Niessner, Jacob Schlesinger, Matthew Spiegel, and Yongxiang Wang for their comments and suggestions. Goetzmann: william.goetzmann@yale.edu, Hamao: hamao@usc.edu, Takahashi: httheory@gmail.com.
} 
"If you wanted to find out what Toyota Motor Corp., NTT Docomo Inc. and Canon Inc. earned last year before they reported results, the best guide wasn't analyst or company predictions. It was the Nikkei newspaper..... Of the 45 Nikkei articles analyzed by Bloomberg News that contained profit figures that preceded the formal release results, 37 gave a number that was within 10 percent of the company's result, or predicted a range that turned out to be correct."

"... But in Japan, regulators seem to have turned a blind eye to the "Nikkei previews," allowing stories appear and then, within a few hours, letting companies issue rote statements saying the stories are not based on anything they have announced..... Last year the Nikkei announced it would no longer supply instant English translations of stories to its 364,000 online subscribers. But given that between 60 and 70 per cent of trading in Tokyo stocks is by foreigners, the effect of publishing earnings previews in the local language only is akin to

"insider trading", says Mr. [Nicholas] Smith of CLSA [in Tokyo]"2

\section{Introduction}

With about three million subscribers (in 2008), Nihon Keizai Shinbun ("Nikkei Newspaper," or "Nikkei" for short) has the $4^{\text {th }}$ largest printed and on-line circulation in Japan. It specializes in business and economy and is almost a "must" read for business people in Japan. ${ }^{3}$ There is a curious institutional phenomenon that has existed for a number of years in the Japanese market. In earnings announcement season, highly accurate sales and/or earnings numbers are reported by Nikkei before the firms' official announcement. These preview announcements appear exclusive to Nikkei, and as we show below, the Nikkei's preview articles are generally more accurate than managements' own most recent publicly disclosed forecasts. In short, they contain value-relevant information.

Regulation Fair Disclosure (Reg FD) was enacted in 2000 in the United States. Its

\footnotetext{
1 Tom Redmont, Toshiro Hasegawa, and Aaron Clark, "Newspaper Has Lock on Prescience Covering Japan Earnings," Bloomberg News, August 7, 2014.

2 Ben McLannahan, “Nikkei previews' spur complaints of home advantage in Tokyo," Financial Times, August 5, 2014.

3 The ranking of Japanese newspapers on circulation is as follows: 1. Yomiuri (circulation: 10 million); 2. Asahi (8 million); 3. Mainichi (3.9 million); and Nikkei (3 million); source: World Press Trends 2008, World Association of Newspapers. In comparison, the circulation of The Wall Street Journal is 2.3 million, and Financial Times is 650,000. Source: The Alliance for Audited Media and Deloitte.
} 
intent was to create a level informational playing field for participants in the U.S. equities markets. The regulation stopped selective disclosure of value-relevant information about publicly traded companies. Corporations could no longer favor specific analysts or disclosure channels. Prior to its enactment, large institutional investors raised objections to Reg FD. Selective disclosure presumably gave large investors an edge - the potential to trade on information before it became widely known. Cohen, Frazzini, and Malloy (2010) find evidence that Reg FD significantly impacted returns to well-connected U.S. mutual fund managers, suggesting that selective disclosure was one source of excess return. Research on the effects of Reg FD suggests that it improved liquidity and increased trading volume (Heflin, Subramanyam, and Zhang 2003; Bushee, Matsumoto, and Miller 2004 and Bailey, Karolyi, and Salva 2006). Researchers have found that cost of capital and liquidity effects have led to voluntary adoption of Reg FD standards by cross-listed firms even though they are explicitly exempt (Francis, Nanda, and Wang 2006; Crawley, Ke, and Yu 2011). Chen and Matsumoto (2006) find that analysts' forecasts were more accurate prior to the barring of selective disclosure and document a correlation between favorable recommendations and selective disclosure; suggesting a quid pro quo relationship based on information.

In general, the empirical evidence on selective disclosure, gleaned from studies around the promulgation of Reg FD in the year 2000 indicate that, prior to the law, publicly traded firms faced a tradeoff between liquidity and price efficiency. The research literature has not yet completely explored this tradeoff.

One of the challenges in studying the effect of selective disclosure on market prices, volatility and liquidity around Reg FD is that there is little cross-sectional variation. When 
the law was enacted, it applied universally across firms with respect to information affecting the value of their common stock (except for cross-listed companies). In contrast to the U.S. market, in Japan, there is heterogeneity in the institutional structure for information disclosure. Some firms choose to regularly communicate with Nikkei for preview articles prior to the official release of earnings and sales information while others do not. This heterogeneity provides us an opportunity to examine corporate tradeoffs between liquidity and price efficiency.

The fact that selective disclosure is intermediated by a single news source introduces an additional level of usefulness. Nikkei - rather than the corporation - may realize the benefits of intermediating value-relevant information. Once Nikkei reporters have met with corporate executives to gather information for the preview article, they effectively share the potential value of this non-public information.

As a newspaper/news service, Nikkei presumably disseminates information to all subscribers simultaneously, however in doing so, it creates a potentially exploitable event a disclosure date that is likely to have an effect on stock prices. Nikkei revenues derive from circulation to individual investors and subscriptions to data feeds to institutional clients. Both groups would recognize the potential benefits of an accurate preview of an adjustment to prior earnings forecast. However, if one group knew before-hand the content of the preview, the potential for exploiting other Nikkei subscribers is significant. In this study we are not able to discern how some investors become aware of Nikkei previews prior to publication, and furthermore this is not the focus of the paper. Rather we are interested in using these events as a means to understand which firms find selective disclosure more beneficial and 
why.

We hypothesize that firms held widely by institutional investors have an incentive to do previews that would allow fund managers to generate positive alpha. Jiang and Sun (2014) provide evidence consistent with this hypothesis for U.S. mutual funds. Stocks held by firms taking unusually high positions in the company around earnings announcements experience positive returns. The authors interpret this as evidence that some fund managers in the U.S. trade on private value-relevant information about earnings surprises. On the other hand, firms that are closely held - for which adverse selection is a significant concern for uninformed investors - are more likely to eschew selective disclosure which would exacerbate bid-ask spreads and illiquidity.

We further hypothesize that the particular information structure we identify in the Japanese market allows informed investors to exploit pre-earnings announcement previews in order to trade in an environment that is less suspicious of adverse selection. Unlike earnings announcement dates which are known in advance, Nikkei previews are not prescheduled and thus can be scheduled unexpectedly prior to announcement at a time when noise-traders and market-makers are less likely to expect to trade against informed traders.

Some accounting research has approached selective disclosure from the behavioral angle. DellaVigna and Pollet (2009) attribute attenuated price response around earning announcements on Fridays to investor inattention. Neissner (2014) finds that managers strategically exploit the inattention effect by disclosing negative information on Fridays. Hand (1990) showed that market prices reacted to the disclosure in annual filings of events disclosed in prior quarters, suggesting that markets only partially react to value-relevant news. 
This is the main hypothesis behind the well-documented post-earnings announcement drift phenomenon (Bernard and Thomas 1989) and the subject of papers by Hirshleifer and Teoh (2003), Hirshleifer, Lim, and Teoh $(2009,2011)$ and others. One broad result of their analysis of accounting anomalies is that these are consistent with limited investor attention and capacity for analysis. In a setting where a large quantity of potentially value-relevant information is disclosed around the same time, the Hirshleifer et al. framework would predict sub-optimal reaction to the news. If, for example, investors use a pecking order to decide which of many securities to trade after a joint earnings announcement, this would lead to trades for which information is considered timely, reliable and significant enough to overcome the cost (in money and attention) of exploiting. Knowing this, the manager of a publicly traded firm who believes the market price fails to incorporate private, positive information would choose to shift the timing of value-relevant news to times when investor information overload is less, to choose a venue in which the disclosure is most credible (i.e., the risk of "cheap talk" is minimal). The management would also prefer disclosure to sophisticated investors who understood its relevance, and for whom the motivation - in terms of trading profits to speculators - is non-trivial.

Recent research has explored corporate use of alternative communication channels to increase awareness about firms around key events such as insider sales and earnings announcements. Bushee, Core, Guay, and Hamm (2009) show that media coverage around earnings announcements mitigate asymmetric information concerns. Fang and Peress (2009) find media coverage is a component of security prices. Lou (2014) documents an increase in advertising expenditure in the year before negative earnings surprises and around a period of 
insider sales. Madsen and Neisner (2014) use observed advertising to rule out reverse causality as a potential explanation for the association between insider sales and advertising expenditures.

Not having Reg FD (as in Japan) presents a set of opportunities for management disclosure strategies. For example, giving one news source with a broad subscriber base an "exclusive" is a means to ensure that the disclosure will be highlighted and will attract sufficient investor attention. Disclosing big changes that are worth the transactions cost to exploit will motivate trading. Finally, and perhaps most controversially, it may be in the interest of a firm whose price suffers from the market's failure to incorporate information, to allow information to leak in advance of a public (and even an exclusive) announcement to ensure that some market participants with the capacity to move prices are sufficiently incentivized to trade.

This strategy may seem contrary to the interest of shareholders, however price inefficiency due to behavioral limitations of the market also presents problems for the corporation and its shareholders. These include higher cost of capital, segmented cost of capital across financing forms and locations, inaccurate compensation rules and categorization at the margins of the firm as a small cap or value stock, with further costs of capital. Selective disclosure that results in speculative profits by informed traders at the expense of uninformed shareholders may be the cost of insuring that the market fully impounds good news. ${ }^{4}$

Although Reg FD and the zero-tolerance enforcement of insider trading laws in the

\footnotetext{
4 There is a long literature about the costs and benefits of allowing insider trading (Fishman and Hagerty 1992; Leland 1992).
} 
U.S. restrict the ability to examine the instances and effects of strategic disclosure, the structure of information dissemination around earnings announcements of Japanese companies allows us to test what is lost and what is gained with Reg FD. While insider trading is against the law, it is not uncommon to see unusual price movement and volume prior to significant events in many markets. This might be a consequence of a free rider problem. Grossman and Stiglitz (1980) point out that a market must compensate investment research through trades that are profitable enough to support it. In such a market, the majority of investors (and firms) can enjoy the benefits of free-riding on price efficiency. However removing channels for profitable research such as private discussions with management reduces the arbitrage in expectations that enforce markets. Information leakage prior to announcements may be one strategy to address free-riding.

In this paper we collect data on Japanese firms around earnings announcements and identify a large sample of preview news articles that report accurate sales and/or earnings numbers. Using this sample we test the following hypotheses using an event study methodology.

First, we test whether preview announcements actually contain value-relevant information. We find that stock returns around positive preview articles are positive and significant, consistent with the hypothesis that firms release value-relevant information prior to the official earnings announcement. We also ask whether - consistent with management seeking to reduce market under-reaction to good news - Nikkei previews that report positive earnings surprises are more frequent. We find that they are: the ratio of positive to negative earnings news in preview articles is 1.63 . Looking more closely at the preview forecasts, we 
find that positive previews are relatively conservative (they are less likely to report numbers higher than those subsequently officially released) and negative forecasts are relatively optimistic (they are more likely to report numbers higher than those subsequently officially released).

In terms of stock price reactions, for non-previewing firms we find that prices rise significantly around release of positive earnings news and drop around release of negative earnings news. For previewing firms we find only a positive price reaction. This is consistent with an endogenous choice made by firms to preview. Firms may only release bad news via a preview when they believe it will not hurt stock price (or will not induce short-selling), and they may release good information via a preview when they believe it will cause a positive price jump.

For previewing firms the significant price movement occurs around the date of the preview article. There is little evidence of a "double reaction" i.e., first at preview, and then once again at the official release of earnings information. In other words, there is little evidence of under-reaction to recent prior news released via Nikkei.

One interesting difference between the reactions around preview articles vs. earnings announcements by non-previewing firms is that the spread in cumulative average residuals (CAR) is persistent over the next two weeks for previewing firms but converges for nonpreviewing firms. If anything, this is evidence for market over-reaction to the official earnings announcement as opposed to the widely documented post earnings announcement under-reaction. This differential is consistent with the hypothesis that the firms use the Nikkei channel to disseminate value-relevant information to sophisticated investors who will 
correctly interpret it and react quickly and permanently to it.

We also document evidence that the value-relevant information is released prior to both official earnings announcements for non-previewers and also for Nikkei previews. Price changes measured from open to open on the day prior to the official announcement (made during trading hours) or the Nikkei preview (available prior to market open) indicates leakage of news. For both groups, the returns on announcement day itself are flat. This is consistent with the hypothesis that information when it appears in the news is already impounded in stock prices.

Taken together, the evidence suggests that Japanese firms use selective disclosure to strategically incentivize market participants to impound positive information into stock prices. Nikkei previews are evidently an important channel. They serve as a coordinating event around which (i.e., before which) informed investors trade and move stock prices. This strategy results in permanent changes to firm market value that are positive, on average. In contrast, price increases due to informed trading in shares of firms that do not preview their results appear to be temporary.

This paper proceeds as follows. In Section 2, we describe the data. Sections 3 through

6 characterize the preview articles in terms of their role as a disclosure medium of information to the market. In Section 7, we examine market's reactions to the Nikkei preview articles. Section 8 investigates incentives and costs/benefits for all parties (Nikkei, companies, investors and regulators). Section 9 concludes.

\section{Data}


During the annual corporate earnings announcement season, all listed firms' announcements are published in the Nikkei Morning Edition in the form of tables. In this table, financial results (sales, operating income, ordinary income, net income, earnings per share, and per share dividends) of the most recent year are tabulated, as well as the numbers from the previous year and management forecast for the next year. Similar announcements are made and tables are published, at the half-year point, again on the day following the announcement. The management forecast of the coming half-year may be updated, based on the information available to the firm at this time. This management forecast is reported by almost all listed firms (Kato, Skinner, and Kunimura 2009). Management forecasts may be revised, not only in half-year intervals, but also when there is a substantive new information about corporate performance. These "stand-alone" revisions of management forecasts are also reported in Nikkei the next day. Due to the internationalization of the Japanese equity market, beginning in 2004, the Tokyo Stock Exchange started to encourage its listed firms to report quarterly figures, in addition to half-year results. Quarterly reporting became mandatory from October, 2008. Now all firms announce cumulative quarterly results. Management forecasts, however, are not on quarterly basis, and announced only on a half-year basis and stand-alone basis.

In addition to the tables of corporate financial reporting, Nikkei writes text articles on some selected firms. In another paper, Goetzmann, Hamao, and Takahashi 2014) we use sentiment analysis applied to the text content of these articles in order to examine the interaction between price, sentiment and news.

Like all news organizations, Nikkei also writes about companies as other news occurs. 
However, before the annual, semi-annual or quarterly financial performance is officially announced by a firm, Nikkei often writes articles that effectively "preview" the results.

We extract all news articles that appear to have information on performance figures that are about to be announced from a database of over a million Nikkei text articles from 2000 to 2010, using text searches. We rely on keywords that refer to fiscal year, unit (Japanese

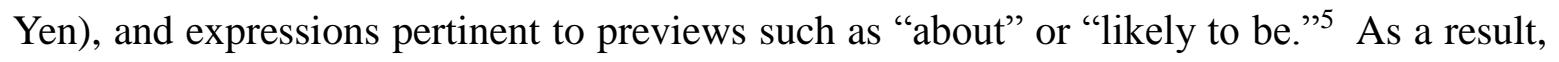
we obtain more than 8,000 potential previews, although the actual number may be more. After extraction, we read all of them and isolate articles that preview financial results, prior to actual announcements. These articles explicitly discuss forthcoming figures on sales and/or operating income and/or ordinary income and/or net income. Also, we exclude articles that mention other accounting matters such as cash flow or asset turnover, but do not mention earnings related figures. Although some firms announce both consolidated and parent-only results, especially in the early years of our sample, we put priority on consolidated financial reporting over parent-only. We look at annual (full-year) and second quarter (half-year) earnings reports. For cumulative quarterly figures, net income is mostly not written up on preview articles. Therefore, we take numbers in the following order of priority: 1 . Net income; 2. Ordinary income; and 3. Operating income.

We set the following rules to capture preview articles. First, the preview article has to appear after the last management forecast update (published the next day by Nikkei) prior to the annual (full-year), or half-year earnings announcement. Second, we take a conservative 60 calendar day period before the actual earnings announcement date (including the

\footnotetext{
${ }^{5}$ For instance, Nikkei article reports that "(Firm name)'s net income at (fiscal year) is likely to be about (preview figure), and this figure is the best ever for this firm."
} 
announcement day itself). We drop preview-like articles written about firms' financial performance appearing a long time before the announcement, since they are not immediately value-relevant. Note that we do include "zero day" preview articles that are published on the day of announcement, a few hours ahead of the actual release by the firm. Third, we do not include preview-like articles that discuss only sales, but not income (ordinary, operating, or net) figures. As a result, our final sample contains 2,899 preview articles. Table 1 shows the details of the number of articles.

To our knowledge, the "preview" phenomenon has not yet been documented in the academic literature. We thus characterize our data in a descriptive fashion below. Some summary statistics are therefore deferred to sections below as needed.

\section{Timing of the Preview Articles}

First, we calculate the number of days before the actual announcement (calendar day difference between Actual Announcement Date minus Nikkei Preview Printed Date). We also calculate days after the latest management update, which is the calendar day difference between Preview Publishing Date minus Management Forecast Update Announcement Date (Nikkei publishes these updates in the next day's paper).

Figure 2 shows the number of preview articles. The horizontal axis represents that calendar days prior to the announcement date. From 60 days prior to the announcement date, the frequency of preview articles increases gradually, but from 7 calendar days before the announcement, it increases above 100 per day. On the day of the announcement (Day 0), the number of preview articles peaks.

Figure 3 shows the frequency of appearance of preview articles over time, from 
January 2000 to December 2010. The articles appear more frequently from 2008, reflecting the fact that quarterly reporting (numbers reported are cumulative) became mandatory from that year.

Table 2 summarizes the timing of the preview articles. These articles are written close to the actual company announcement. The mean and median number of days before the announcement are 19.44 and 14 days respectively, but many appear on the day of the announcement (the mode is 0 , i.e., the morning of official announcement), and after the update of the latest official management forecast (mean of 120 days, median of 85 days).

\section{Are the Previews Biased?}

In this paper we make the assumption that the firm itself voluntarily communicates with Nikkei prior to the official announcement. We have no explicit evidence on the precise nature of this information channel. Under the assumption that selective disclosure by the firm (via whatever channel) is a strategic decision, it is of interest to see if preview articles have a bias toward positive or negative forecasts. Kato, Skinner, and Kunimura (2009) find a positive bias in initial management forecasts, issued at the time of the release of the most recent year's results. We test to see if this is true of the Nikkei previews as well.

We divide the preview sample to two groups: (1) the figures actually announced turned out to be strictly better than the most recent management forecast update; and (2) the announced figures came out to be worse than (or equal to) the most recent management forecast. We use the management forecast as a benchmark because in Japan analysts do not 
conduct earnings forecasts actively, and there is no average or consensus forecast. ${ }^{6}$ In case (1) above, we count the number of preview articles as "over" forecasting if they state numbers higher than the actual announcements, "under" forecasting if they are below the management forecasts, and "between" if they are in between the actual and management figures. In case (2), the "over" forecasts are when the preview articles point to numbers above the management forecasts, "under" forecasts are when previews mention estimates below the forthcoming announcements, and "between" when the previews lie below the management forecasts but above the actually announced numbers. If a preview article mentions two or more of sales, operating, ordinary, and net income, they are counted as separate reports (thus the total number of previews is 5,119 ).

Table 3 shows the breakdown of counts of the preview articles. Information contained in the previews is more often "good news." Out of 5,119 reports, 3,155 (61.6\%) of them are written when actual performance is going to be better than the most recent management forecast (i.e., positive earnings surprise); whereas 1,964 (38.4\%) of them are written when the announcement is going to be below the forecast (i.e., negative earnings surprise). Within the "good news" cases, about 70\% of them are "modestly optimistic" and do not over-shoot in a sense that the previews report numbers in between the prior management forecast and the actual announcement. About $23 \%$ of the articles report higher number than actual, and only $7 \%$ of them under-forecast performance (i.e., the preview forecast is in the wrong direction). On the other hand, for bad news $50 \%$ of previews report numbers in between the recent management forecast and the actual (i.e., bad news is softened, or under-played in the

\footnotetext{
${ }^{6}$ Ota (2006) finds that Japanese analyst forecast is generally of less quality than management forecast.
} 
preview articles), and $44 \%$ of them report worse figures than the actual (i.e., overplay bad news). Only $6 \%$ of the articles go in wrong direction (over-forecast).

The ratio of good-news to bad-news articles is consistent with management taking action to highlight positive earnings surprises, as opposed to a journalistic desire to attract readership by equally reporting both positive and negative surprises. To the credit of both management and Nikkei, $38.4 \%$ of articles are bad-news. This is a substantial fraction, and strong evidence of a functional, efficient information structure in Japan. The imbalance is also not surprising in light of the long-documented phenomenon in the U.S. that analysts upgrades of stocks are much more common than downgrades. This imbalance in the U.S. was generally attributed to selective analyst access to management prior to Reg FD, presumably based on a strategic choice by firm management. The ratio of positive to negative earnings surprises in Japan is also consistent with the strategic choice by the firm and the press. Of course there are other possible explanations that may be tested; e.g., prior management forecasts may be conservative or Nikkei subscribers prefer news about positive earnings surprises (perhaps due to the relative difficulty in exploiting negative news).

The asymmetry in the over- vs. under-prediction has the result of rendering the official announcement following the Nikkei preview article relative good news in the case of both positive and negative earnings surprises. In the case of the positive earnings surprises, the official announcement has a $70 \%$ probability of being better the Nikkei preview. In the case of negative earnings surprises, the official announcement has a $44 \%$ of being better than the Nikkei preview. This is consistent with a strategic prior management forecast. For example, Cheng and Lo (2006) find that U.S. firms strategically manipulate forecasts to 
reduce share prices prior to insider purchases. As we discuss below, we examine various theories about the extent to which the market properly adjusts for strategic information release. In simple terms, however, is the market "fooled" by the bias in over- or underprediction in the previews?

\section{Which Firms Are the Subject of Previews?}

Nikkei does not write preview articles on all publicly traded firms. We examine which firms are written-up and how persistent it is. This is important, because investor reaction to the news is based upon expectations conditional upon the information channel and potentially understanding and relying on repeated patterns of disclosure. If management uses Nikkei previews in a strategic game of selective disclosure, do the market participants understand and rely on the rules of this game?

There are 1,065 firms that are previewed at least once by Nikkei (the numbers of listed firms are 3,488 in December, 2000 and 3,693 in December, 2010). Table 4 shows the yearly counts of preview articles for the most frequently written-up firms. While some of the names of those firms may be familiar due to their widely known consumer products, it is not obvious from inspection of the table what types of firms are more frequently previewed. For the analysis we develop below, we single out firms that was previewed in the prior year, and then previewed again in the current year. For these firms, investors may expect the preview articles to appear in the current year as well, and so it indeed appears. We examine these firms in comparison to firms that are never previewed by Nikkei in terms of market reactions to the events such as preview publications and company announcements. We find 800 firmyear observations of these firms, which we call "serially-previewed" firms. As a control, we 
create a sample of market-cap matched firm-year observations for the firms that have no previews published in 2001 - 2010. Table 5 reports firm characteristics of "seriallypreviewed" and "never-previewed" firms.

Table 6 presents the results of a probit regression on the characteristics that distinguish "serially-previewed" from "never-previewed" firms. The table shows that larger firms with relatively high turn-over (i.e., liquidity) are more likely to be previewed. This is not surprising in light of Nikkei subscribers and market position. Big, widely held and traded companies are obviously of interest. From the perspective of traders who have the benefit of selective disclosure, the higher relative liquidity of these firms means that price impact is lower and hence trading profits on private information more profitable. The different specifications of the regression in Table 6 are also instructive. Not controlling for size, the

proportion of foreign ownership (as opposed to Japanese domestic institutional ownership) is a positive predictor of previewing behavior. This is interesting in light of Nikkei's recent decision to release preview articles in Japanese language only - presumably giving domestic investors a slight edge in interpretation of the subtlety accompanying and interpreting the numbers (a more complete analysis of this soft information component is the subject of our on-going research).

\section{Accuracy of Previewed Results}

The Nikkei preview articles are equivalent to "selective disclosure" in the pre-Reg FD U.S., except that they are published (solely) by Nikkei. A natural question is whether such previews are more accurate than previously available forecasts. We compute and 
compare forecast errors for the most recent management forecast and the forecast in preview articles. Table 7 reports the results.

Since there are relatively more preview articles published from seven calendar days before to the day of firms' announcements, we also look at the accuracy of the $[-7,0]$ previews. Table 7 shows that these preview forecasts are much more precise than the updated management forecast. Further, within the $[-7,0]$ previews, we separate "serially-previewed" firms. This table essentially documents that the preview news is potentially value-relevant. Tables 8-1 and 8-2 report the accuracy of the preview forecast, compared with that of the latest management forecast. Table $8-1$ is for all previews; $8-2$ is for serial previewers, $8-3$ is for the non-serial previewers. Table $8-4$ is a test of the difference between the serial previewers and the non-serial previewers. Serially previewers have consistently more accurate information.

\section{Price Effects around Previews and Company Announcements}

Kyle (1985) is the main theoretical framework for empirical predictions about rational investor behavior in a market with asymmetric information - as trading goes to continuous time, prices are fully revealing and martingale, and speculators make positive profits thanks to "noise traders." As a first step we test whether price dynamics around information events allow profits to informed investors. As a second step we examine the dynamics of various proposed microstructure measures. If, for example, strategic disclosure has benefits for the firm and its shareholders by improving price efficiency, there might be

tradeoffs along other dimensions such as bid-ask spreads, lower volume and/or higher volatility. 
Figures 4A and 4B illustrate the basic price results. For previewing firms (Figure 4A) we find a positive price reaction to positive news but no negative price reaction to negative news. For non-previewing firms, 4B, prices rise significantly around the release of positive earnings news and drop around the release of negative earnings news. We also document evidence that the value-relevant information is released prior to both official earnings announcements for non-previewers and also for Nikkei previews. Price changes measured from open to open on the day prior to the official announcement (made during trading hours) or the Nikkei preview (available prior to market open) indicates likely leakage of news. For both groups, the returns on announcement day itself are flat. As pointed out above, this is consistent with the hypothesis that information when it appears in the news is already impounded in stock prices, and with a rational model of investor decision-making in the presence of asymmetric information where the probability of informed trade is correctly estimated by uninformed investors.

The flat CARs for bad news are consistent with the hypothesis discussed above that firms may only release bad news via a preview when it is not expected to hurt stock price (or to not induce short-selling). The figures also show that the spread in CARs is persistent over the next two weeks following preview announcements but it converges for non-previewing firms around the official announcement. This suggests that the market may over-react rather than under-react to the official earnings announcement.

The post-earnings announcement drift is documented in other countries, most prominently in the U.S., but is less prevalent in the Japanese market. It is generally believed to be associated with behavioral limitations of investors. Given the regulatory structure of 
the U.S. market it makes it difficult to test cross-sectional differences in post earnings announcement drifts (PEAD) dependent upon different strategies for selective information disclosure by firms. The Japanese evidence suggests that firms use the Nikkei channel to disseminate value-relevant information to investors around earnings announcements, and these are effective at addressing potential under or over-reaction. The over-reaction around the official announcement days is a puzzle and the subject of further analysis.

Figure 5 shows the price dynamics for previewing firms sorted out by the number of days separating the preview announcement and the official announcement. CARs are synchronized around the event day defined by the official news announcement. It shows no evidence of a "double reaction" i.e., first at preview, and then once again at the official release of earnings information. There is little evidence of under-reaction to recent prior news released via Nikkei.

\section{Incentives, Costs and Benefits of the Nikkei Previews for Related Parties}

Market microstructure research (Admati and Pfleiderer 1988) predicts that the presence of asymmetric information should be empirically manifested in lower volume (i.e., buyers and sellers trading on their disagreement between about the economic value of the security), higher volatility (arguably a measure of disagreement), and an increase in bid-ask spreads (indicative of concerns about adverse selection by market-makers), as informed and uninformed investors strategically adjust the timing of their trades to maximize profitability or minimize adverse selection.

Our hypothesis is that preview articles provide an opportunity for informed traders to exploit an environment with lower spreads (hence less concerns about adverse selection). 
As earnings season approaches, investors will naturally anticipate increasing probability of informed trades. News services provide an earnings calendar with expected dates for earnings releases. Investors use this information to assess the likelihood of informed trading. Krinsky and Lee (1996) show that spreads related to adverse selection increase prior to earnings announcements in the U.S. market. In contrast, the dates of the appearance of preview articles are not public, thus spreads may not increase as much in days prior to previews, making informed trading more profitable. In other words, the preview - particularly if it is not by a serially previewing firm, may be a strategy for allowing more profitable exploitation of private information. In the spirit of Admati and Pfleiderer (1988), the preview can be used to create an information event before which informed traders can trade in a less-suspicious environment.

Table 9 reports average daily bid-ask spreads for three intervals abound previews and official announcement days. For official announcement day spreads we construct a matched sample of non-previewing firms based on size in the same fiscal year. We divide the table into good news and bad news events. We first test whether the spreads around preview days are higher or lower than the spreads for a matched sample of non-previewing firms on the days around official earnings announcement days.

Our null hypothesis is that the spreads are the same. Our alternative is that the bidask spreads for the day of the release of value-relevant information to informed traders -when the date is known ex-ante -- are greater than when the date is not known ex-ante. For good-news announcements, we find that spreads are significantly lower for previewers compared to non-previewers prior to and around the event date. Evidence reported above 
helps us assess market expectations about the timing of information released to informed traders. For official earnings announcement days, we show above that prices move a day or two before the release date. If the timing of this selective disclosure is common knowledge, then we would expect spreads due to adverse selection to increase over the same time interval. In contrast, if the day of the selective disclosure prior to a preview is unknown, or at least less predictable than disclosure dates preceding announcement days, then this would imply a significantly lower adverse selection-based bid-ask spread prior to previews compared to official announcements.

We find strong evidence against the null. For the -3 to -1 day window, in which stock prices have been shown to move in the direction of earnings revisions, the difference in the bid-ask spread is significant for both good news and bad news events. For good news events, the difference in spreads are significant in all three intervals: $t-10$ to $1-4, t-3$ to $t-1$ and $t=0$. For bad news events, the $\mathrm{t}-10$ to $\mathrm{t}-4$ and $\mathrm{t}=0$ intervals are not significant. [check one-tailed test].

Table 9 shows several other interesting things. Note the change in spreads from the period t -10 to $\mathrm{t}-4$ to $\mathrm{t}-3$ to $\mathrm{t}-1$. For previews, this increase is small. For the matched sample, the increase is large. Spreads widen considerably in the three days prior to the official announcement compared to the preview sample, consistent with a rational anticipation of leakage in the days immediately preceding the announcement. The difference between the spreads in these two event windows is significant for the matched sample and not for the preview sample (check). Another feature of note is that the average spreads are significantly higher for bad news than for good news for all reported windows, for both the preview and 
matched samples. This is a puzzle. It is consistent with the hypothesis that investors are more sensitive to negative disclosures compared to positive disclosures, however it is inconsistent with the hypothesis that firms are more likely to disclose positive information. In a "game" of selective disclosure we noted above that companies appear to allow positive information to reach the market prior to preview or announcement, which would increase the probability of private information rather that decrease it when that information is good news.

One additional complicating factor relevant to the interpretation of Table 9 results is that the decision to preview may be conditional upon price trends or bid-ask spread trends. For example, a firm planning to preview might not do it if the spreads or prices suddenly spike upwards, eliminating the benefit or necessity of selective disclosure via managementrelated channels.

\section{Discussion and Conclusion}

The Nikkei preview phenomenon provides a unique opportunity to examine the selective disclosure strategies that differ from the current practice in the U.S., which is constrained by Regulation FD, and from the disclosure practice that prevailed in the U.S. prior to the enactment of Reg FD. Nikkei's virtual monopoly on media release of earnings numbers prior to official announcement allows us to use one specific channel of press disclosure.

The structure of information release in Japan offers a means to more sharply differentiate the response by investors to different types of information. Prior research on investor response to the probability of information asymmetry. has relied on more general information structures. Vega (2006) for example, uses the Easley and O'Hara (1992) PIN 
measure to show that post-earnings announcement drift is lower when the probability of informed trading is higher. Our results are consistent with hers, but support the hypothesis that firms may play a decisive role in moving prices towards efficiency. Our also results provide additional insight into those reported by Tetlock (2010). While he also detects evidence of informed trading prior to the news, and documents a negative association with a liquidity, which is mitigated upon the news release. We are able to separate the release of information into two types: one for which the date of release is well-anticipated, and one for which it is less-so. We find that this leads to different patterns of investor behavior, and consequently different behavior of asset prices.

We are able to document several features of the Nikkei preview phenomenon that suggest that it is strategically used by corporations to improve price efficiency. Preview numbers are more accurate than prior forecasts, which themselves may be strategically formed to ensure that the Nikkei updates are more likely to be perceived as good news. Price reactions around previews are positive for good news and flat for bad news. The company stock price on average benefits from this disclosure event and the benefits are permanent in contrast to temporary effects around official earnings releases. This suggests that the prices discovered via the Nikkei preview process are efficient.

We find evidence that an early disclosure via Nikkei preview is accompanied with leakage prior to the preview event, resulting in a rise in share price before article publication. Price dynamics indicate that leakage occurs for official earnings announcements as well. By the same token, the absence of price movements on the actual day of information release suggests that uninformed as well as informed investors adjust their priors about the 
probability of informed trading. Evidently the fact that one sees something in the news is prima facia evidence that prices already incorporate it. We find some evidence that uniformed investors are motivated to trade by a company appearing in the news - evidence documented in earlier markets. We also find that prices that were moved by the news (around the official earnings announcements) later revert - suggesting that there were not based on value-relevant economic fundamentals.

Taken together, these phenomena suggest that the previews play a role in a complex strategic interaction among several parties. We conjecture that previews allow informed agents to trade in advance of wider spreads associated with adverse selection concerns around the official earnings announcement. The company may use Nikkei as the informational intermediary to facilitate this trading, and in doing so may weigh the costs and benefits of informed trading in its shares when selecting whether to preview.

The natural question is why this particular information revelation structure suits the various parties: firms, Nikkei, investors and regulators. From the firm's perspective, the benefits to informed trading enumerated in Leland (1992) are straightforward: stock prices are higher, cost of capital lower, market prices are more fully revealing and investor risk is reduced. The cost to shareholders who sell shares at an adverse price may be small compared to the net benefits to long-term shareholders of the firm.

Viewed through the lens of behavioral finance, previews provide opportunities for firms to reduce investor inattention and its adverse effects on share price and liquidity - to the extent that one component of liquidity is a consequence of breadth of ownership and awareness. Barber and Odean (2008) document the strong positive price effects of awareness 
due to stocks being in the news.

From Nikkei's perspective, the ability to provide timely, accurate and exclusive information about corporate performance is the hallmark of a leading financial news provider. By serving as the principal medium for selective corporate disclosure they make themselves highly valuable to subscribers and to companies.

From the perspective of various investor clienteles, the incentives are mixed. For investors who trade prior to news release, there is a potential enforcement risk if indeed their trades violate insider trading laws, however the performance benefits may be significant. We have not yet examined changes in institutional holdings to understand which clienteles exploits these opportunities. Bris (2005) documents a trade-off between profitability and enforcement of insider trading laws. In the Japanese case the sustained evidence of informed trading prior to the event may thus be associated with modest profitability.

From a regulator's perspective, one of the principal motivations of Reg FD was the promotion of liquidity through the reduction of information asymmetry. Improved liquidity seems like a good think, although as the volume of trade by uninformed speculators increases, so do uncompensated transactions costs. In our study, since the decision to use previews is endogenous, liquidity differences between previewing and non-previewing firms will not likely be informative, and thus this paper does not address net welfare benefits of a non-Reg FD environment.

The case of Japan's Nikkei preview articles demonstrates that, in the absence of Reg FD, a richer strategy space for information disclosure, timing of trades and avoidance of adverse selection emerges. 


\section{References}

Admati, A, and P. Pfleiderer. 1988. "A Theory of Intraday Patters: Volume and Price Variability." Review of Financial Studies 1: 3-40.

Bailey, W., G.A. Karolyi, and C. Salva. 2006. "The Economic Consequences of Increased Disclosure: Evidence from International Cross-Listings." Journal of Financial Economics 81: $175-213$.

Bailey, W., H. Li, C.X. Mao, and R. Zhong. 2005. "Regulation Fair Disclosure and Earnings Information: Market, Analyst, and Corporate Response." The Journal of Finance 63: 24872513.

Bernard, V. L., and J. K. Thomas. 1989. "Post-Earnings-Announcement Drift: Delayed Price Response or Risk Premium?” Journal of Accounting Research 1-36.

Bris, A. 2005. “Do Insider Trading Laws Work?” European Financial Management 11: 267312.

Bushee, B., D. A. Matsumoto, and G. Miller. 2004. "Managerial and Investor Responses to Disclosure Regulation: The Case of Reg FD and Conference Calls." The Accounting Review 79: 617-643.

Bushee, B. J. Core, W. Guay, and S. Hamm. 2009. "The Role of the Business Press as an Information Intermediary." Journal of Accounting Research 4: 1-19.

Chen, S., and D. A. Matsumoto. 2006. "Favorable versus Unfavorable Recommendations: The Impact on Analyst Access to Management-Provided Information." Journal of Accounting Research 44.4: 657-689.

Cheng, Q., and K. Lo, K. 2006. "Insider Trading and Voluntary Disclosures.” Journal of Accounting Research 44: 815-848.

Chung, D., and J. Lee. 1998. "Ownership Structure and Trading Volume Reaction to Earnings Announcements: Evidence from Japan." Pacific-Basin Finance Journal 6: 45-60.

Cohen, L., A. Frazzini, and C. Malloy. 2010. "Sell - Side School Ties." The Journal of Finance 65.4: 1409-1437.

Crawley, M. J., B. Ke, and Y. Yu. 2011. "Externalities of Disclosure Regulation: The Case of Regulation FD.” Working Paper, Indiana University.

DellaVigna, S. and J. M. Pollet. 2009. "Investor Inattention and Friday Earnings 
Announcements.” The Journal of Finance 64: 709-749.

Fang, L., and J. Peress. 2009. "Media Coverage and the Cross-Section of Stock Returns." The Journal of Finance 64: 2023-2052.

Fishman, M and K. Hagerty. 1992. "Insider Trading and the Efficiency of Stock Prices." The RAND Journal of Economics 106-122.

Francis, J., D. Nanda, and X. Wang. 2006. "Re-examining the Effects of Regulation Fair Disclosure using Foreign Listed Firms to Control for Concurrent Stocks." Journal of Accounting and Economics 41: 271-292.

Goetzmann, W. N., Y. Hamao, and H. Takahashi. 2014. "Announcements of Earnings and Management Forecasts and Text Format Articles." Working Paper.

Grossman, S., and J. E. Stiglitz. 1980. "On the Impossibility of Informally Efficient Markets." American Economic Review 70:393-408.

Hand, J. R. M. 1990. “A Test of the Extended Functional Fixation Hypothesis.” Accounting Review: 740-763.

Heflin, F., K.R. Subramanyam, and Y. Zhang. 2003. "Regulation FD and the Information Environment: Early Evidence.” The Accounting Review 78: 1-37.

Hirshleifer, D., and S. H. Teoh. 2003. "Limited Attention, Information Disclosure, and Financial Reporting." Journal of Accounting and Economics 36.1: 337-386.

Hirshleifer, D., S. S. Lim, and S. H. Teoh. 2009. "Driven to Distraction: Extraneous Events and Underreaction to Earnings News." The Journal of Finance 64.5: 2289-2325.

Hirshleifer, D., S. S. Lim, and S. H. Teoh. 2011. "Limited Investor Attention and Stock Market Misreactions to Accounting Information." Review of Asset Pricing Studies 1.1: 3573.

Jiang, H., and Z. Sun. 2014. "Dispersion in Beliefs among Active Mutual Funds and the Cross-Section of Stock Returns.” Journal of Financial Economics 114-2: 341-365.

Krinsky, I., and J. Lee. 1996. "Earnings Announcements and the Components of the Bid-Ask Spread. The Journal of Finance 51: 1523-1535.

Kyle, A. 1985. “Continuous Auctions and Insider Trading.” Econometrica 53:1315-1336. 
Ota, K. 2006. "Determinants of Bias in Management Earnings Forecasts: Empirical Evidence from Japan," in Gregoriou, G., and M. Gaber (eds.) International Accounting: Standards, Regulations, Financial Reporting, Elsevier.

Leland, H. 1992. "Insider Trading: Should it be Prohibited?" Journal of Political Economy 100: 859-887.

Lou, D. 2014. "Attracting Investor Attention through Advertising," Review of Financial Studies, in press.

Madsen, J. and Niessner, M. 2014. "Is Investor Attention for Sale? The Role of Advertising in Financial Markets.” Working Paper.

Niessner, M. 2014. "Strategic Disclosure Timing and Insider Trading." Working Paper.

Tetlock, P. C. 2010. "Does Public Financial News Resolve Asymmetric

Information?"Review of Financial Studies 23: 3520-3557.

Vega, C. 2006. "Stock Price Reaction to Public and Private Information.” Journal of Financial Economics 82: 103-133. 


\section{Figure 1. Example of Earnings Announcement on Nikkei Newspaper}

An example of earnings announcement (based on Tan-Shin - Early Reports) published in Nikkei Newspaper.

Nikkei Morning Section, January 30, 2014:

\begin{tabular}{|lllllll|}
\hline キヤノン (7751)米国基準 & & & & 3.28 \\
12.12 & 34797 & 342557 & 224564 & 191.3 & 記 130.0 & \\
13.12 & 37313 & 347604 & 230483 & 200.8 & 130.0 & \\
14.12 予 & 38500 & 360000 & 240000 & 179.9 & 130.0 & \\
\hline
\end{tabular}

Legend of the above:

キヤノン: Canon, 7751: Japanese security code or SEDOL, 米国基準: US GAAP, Date of SH mtg.

Yr. Mo. Sales Cur. Inc. Net Inc. EPS Dividends/share

100M ¥M ¥M $¥ ¥ \quad ¥$

14.12 予: Management forecast for the fiscal year ending December 2014

記 stands for "commemorative dividends" 


\section{Figure 2. Number of Preview Articles Over Time}

This figure shows the time-series distribution of the Nikkei Preview articles, relative to the date of company's announcements. The announcements are on sales and/or operating income and/or ordinary income and/or net income. Our priority rule is to take the last (net income) and go reverse, if not available.

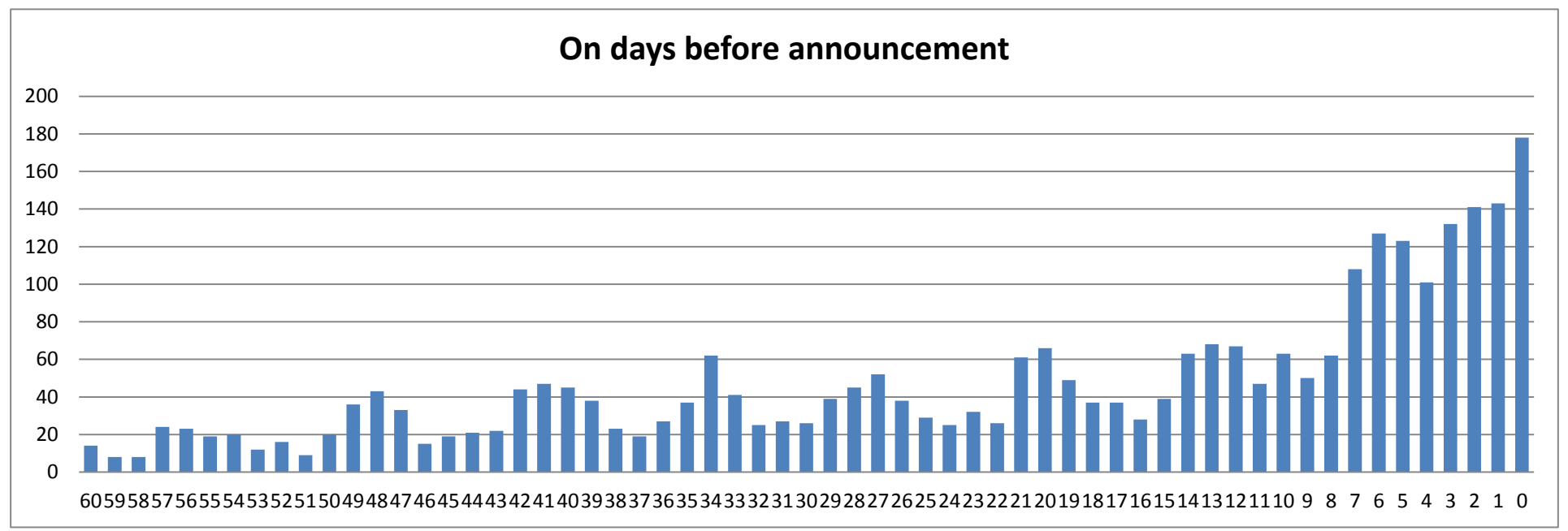




\section{Figure 3. Preview Articles over Time}

The figure shows the time-series distribution of the Nikkei Preview. The announcements are on sales and/or operating income and/or ordinary income and/or net income. Our priority rule is to take the last (net income) and go reverse, if not available.

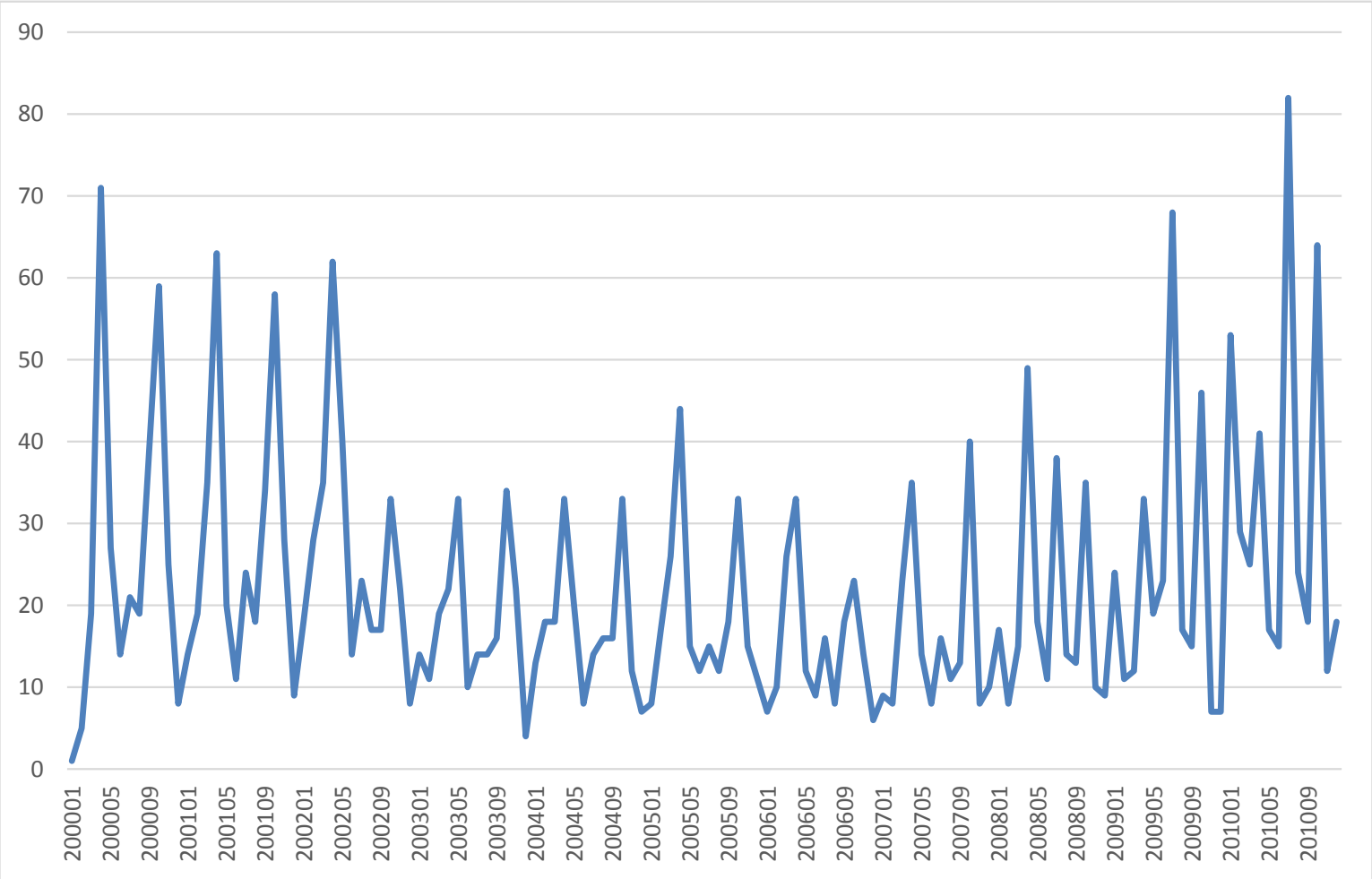


Figure 4A. CARs for Preview Article Publications

"Day0"is the day of the preview article publication.

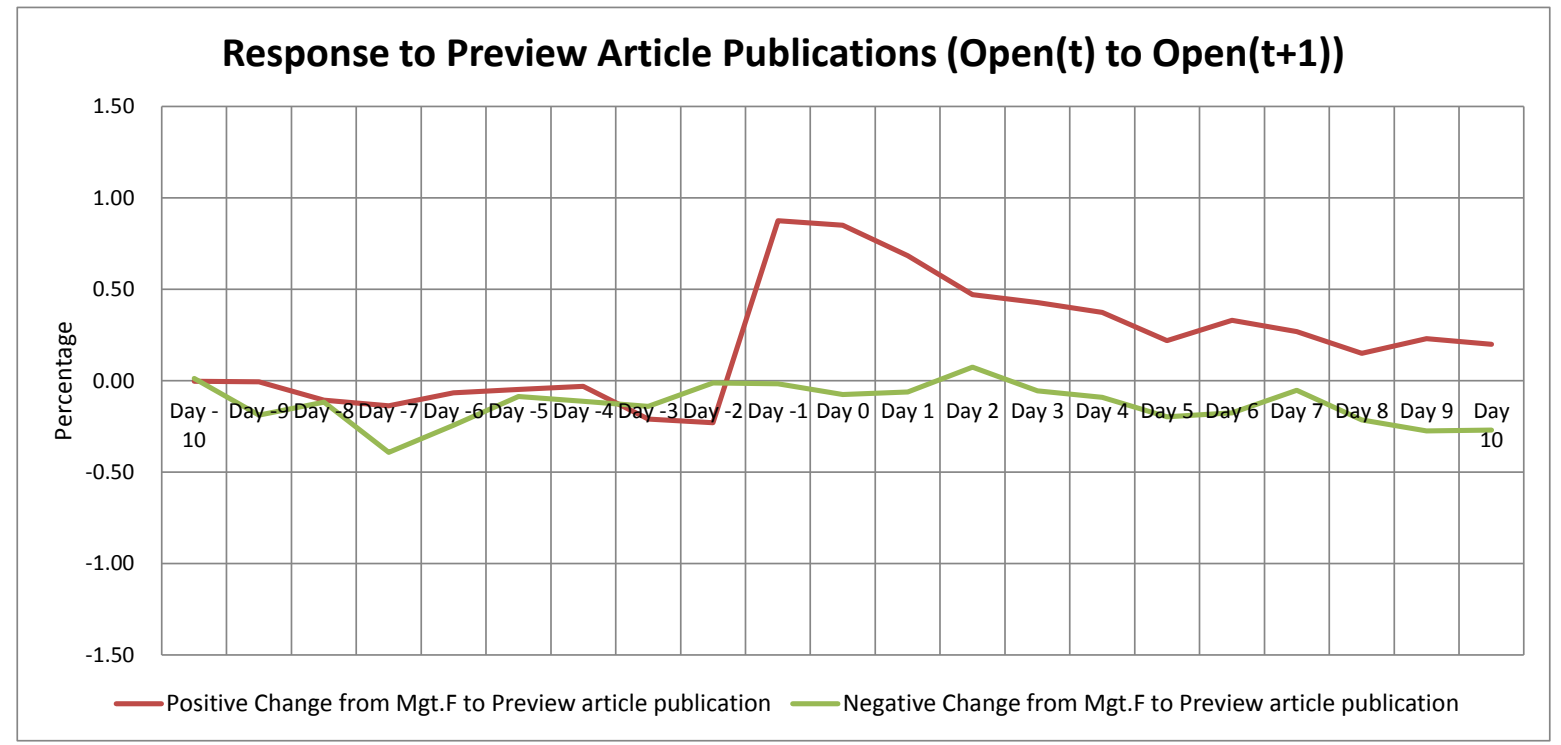

Figure 4B. CARs for Company Announcement Publications (for Non-Previewers)

"Day 0" is the day of publication of company announcement.

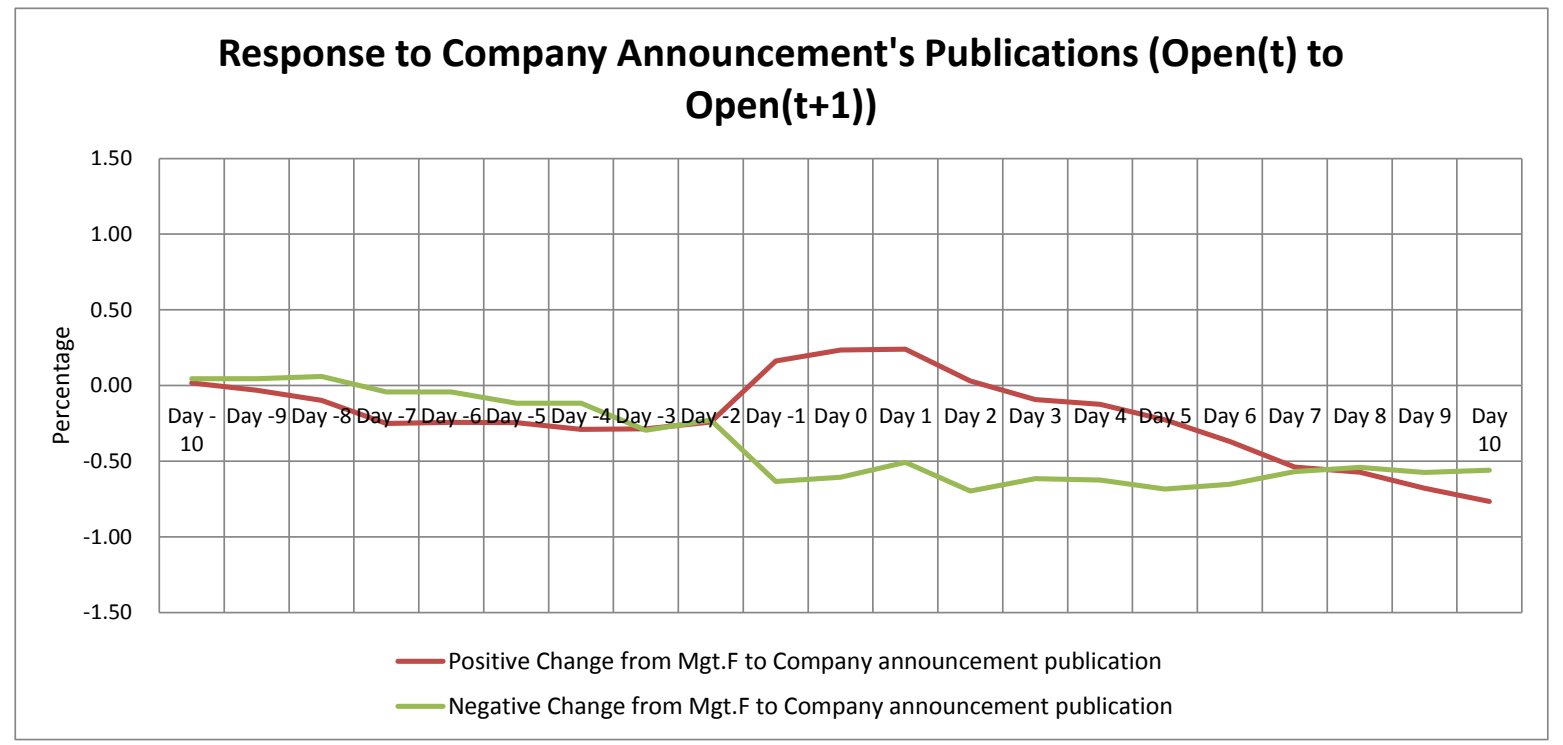




\section{Figure 5. CARs for [-7, 0] Preview Publications}

"Day0"is the day of the preview article publication.

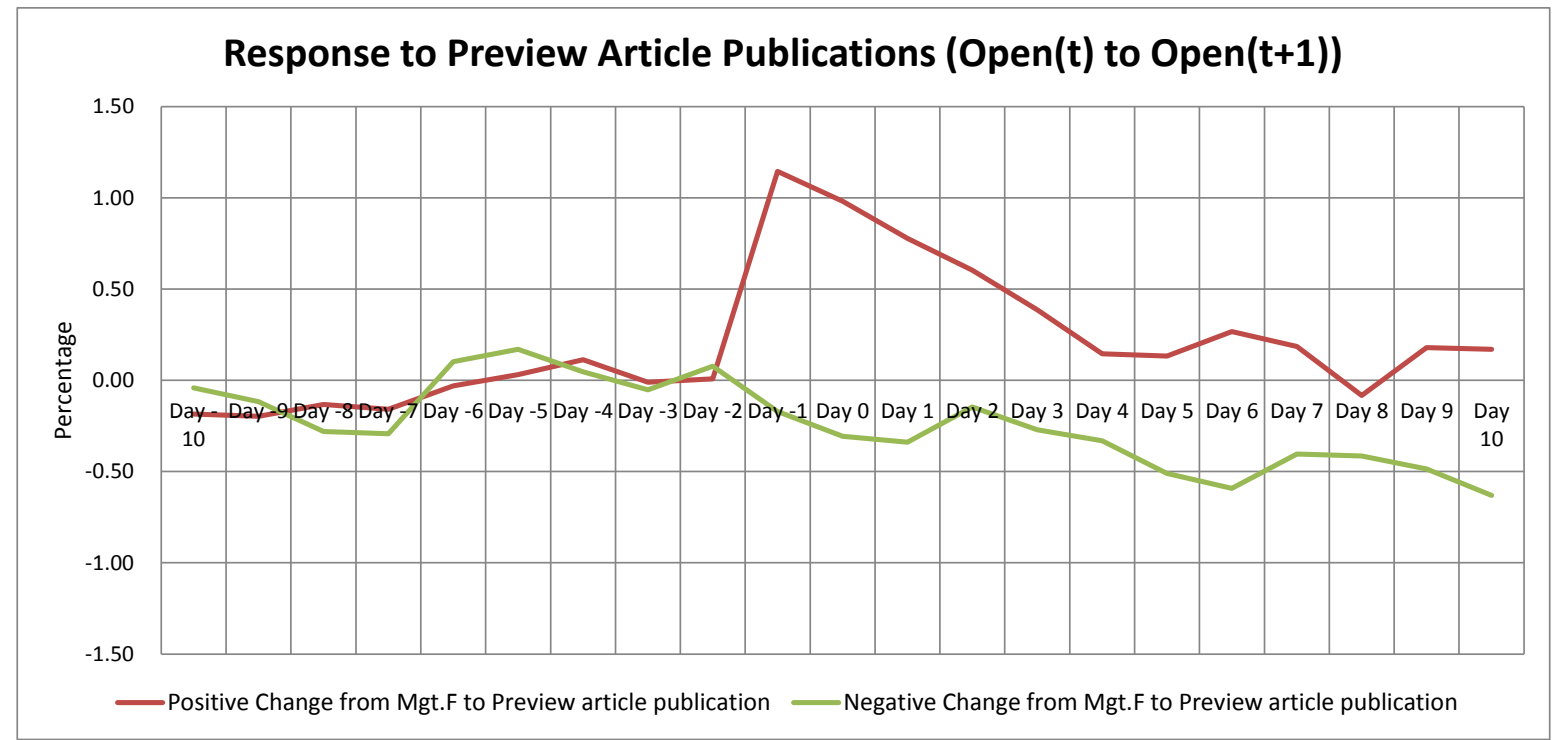




\section{Figure 6. Responses to Company Announcement for [-7, 0] Previews}

This figure reports CARs plotted from 10 days before to 3 days after the company announcement for previewed firms whose articles appeared 7 days before to the day of the announcement. Vertical axis is in percentage. " 0 " is the previews published on the day of the announcement, "- 1 " is the previews published one day before the announcement, etc.

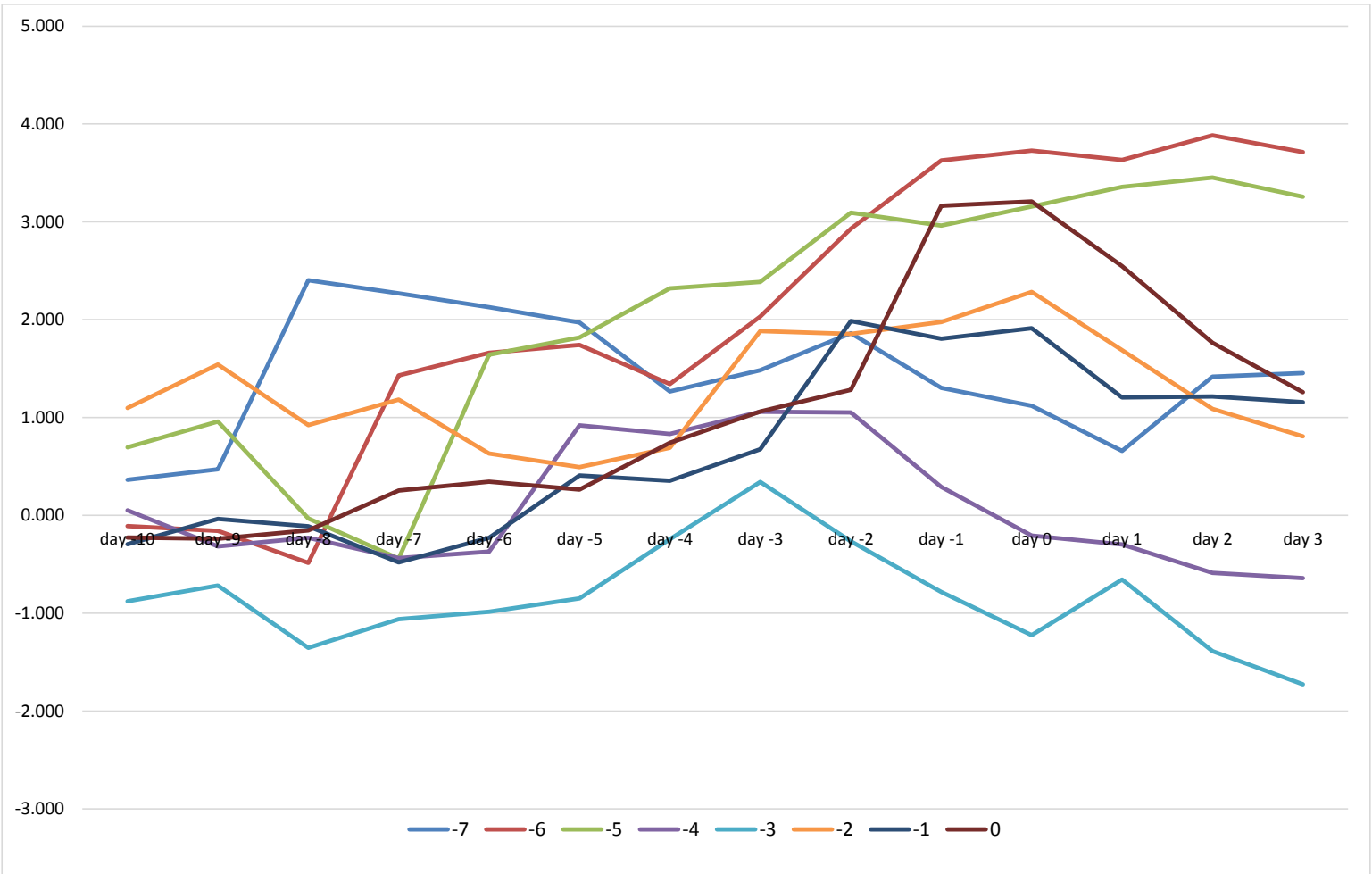


Table 1. Number of Preview Articles

\begin{tabular}{l|r|rrrr}
\hline & \multicolumn{5}{|c}{ Number of articles } \\
\hline Preview about & Total & $\begin{array}{c}\text { Annual (12 month } \\
\text { period) }\end{array}$ & $\begin{array}{c}\text { Quarterly (9 month } \\
\text { period) }\end{array}$ & $\begin{array}{c}\text { Quarterly (6 month } \\
\text { period) }\end{array}$ & $\begin{array}{c}\text { Quarterly (3 month } \\
\text { period) }\end{array}$ \\
\hline Sales & 2,563 & 1,117 & 166 & 957 & 323 \\
Operating income & 1,799 & 734 & 132 & 679 & 254 \\
Ordinary income & 1,684 & 794 & 73 & 671 & 146 \\
Net income & 1,512 & 800 & 51 & 587 & 74 \\
\hline Total & 2,899 & 1,286 & 181 & 1,085 & 347 \\
\hline Grand Total & & \multicolumn{4}{c}{2,889} \\
\hline
\end{tabular}

Table 2. Timing of Publication of Preview Articles

\begin{tabular}{lrrrrrrrr}
\hline Variable & N & $\begin{array}{r}\text { Mean } \\
\text { (days) }\end{array}$ & p25 & $\begin{array}{r}\text { Median } \\
\text { (days) }\end{array}$ & p75 $\begin{array}{r}\text { Min. } \\
\text { (days) }\end{array}$ & $\begin{array}{r}\text { Max. } \\
\text { (days) }\end{array}$ & $\begin{array}{r}\text { Mode } \\
\text { (days) }\end{array}$ \\
\hline Days_before_company_ann & 2,899 & 19.44 & 5 & 14 & 33 & 0 & 60 & 0 \\
Days_after_mgt_update & 2,280 & 120.22 & 79.5 & 123 & 161 & 3 & 374 & 85 \\
Days_between_update_and_company_ann & 2,280 & 141.91 & 93 & 167 & 182 & 7 & 377 & 182 \\
Days_after_prior_company_ann & 619 & 353.67 & 349 & 358 & 362 & 302 & 380 & 362 \\
\hline
\end{tabular}

Table 3. "Biases" in Preview Articles

\begin{tabular}{|c|c|c|c|c|c|c|c|c|c|c|c|c|}
\hline & \multicolumn{6}{|c|}{ Actual > Mgt.forecast } & \multicolumn{6}{|c|}{ Actual < Mgt.forecast } \\
\hline & "Over" & Fraction & "Between" & Fraction & "Under" & Fraction & "Over" & Fraction & "Between" & 'Fraction & "Under" & Fraction \\
\hline Sales & 286 & $26.7 \%$ & 734 & $68.6 \%$ & 50 & $4.7 \%$ & 49 & $5.2 \%$ & 488 & $52.1 \%$ & 399 & $42.6 \%$ \\
\hline Operating income & 48 & $19.5 \%$ & 184 & $74.8 \%$ & 14 & $5.7 \%$ & 6 & $6.4 \%$ & 54 & $57.4 \%$ & 34 & $36.2 \%$ \\
\hline Ordinary income & 221 & $21.5 \%$ & 761 & $74.0 \%$ & 46 & $4.5 \%$ & 14 & $3.5 \%$ & 182 & $45.2 \%$ & 207 & $51.4 \%$ \\
\hline Net income & 179 & $22.1 \%$ & 579 & $71.5 \%$ & 52 & $8.2 \%$ & 41 & $7.7 \%$ & 260 & $49.1 \%$ & 229 & $43.2 \%$ \\
\hline Total & 734 & $23.3 \%$ & 2,258 & $71.6 \%$ & 162 & $6.7 \%$ & 110 & $5.6 \%$ & 984 & $50.1 \%$ & 869 & $44.3 \%$ \\
\hline Grand Total & & & 3,155 & $61.6 \%$ & & & & & 1,964 & $38.4 \%$ & & \\
\hline
\end{tabular}


Table 4. Most Frequently Previewed Firms

\begin{tabular}{|c|c|c|c|c|c|c|c|c|c|c|c|c|c|c|}
\hline & Name & y2000 & y2001 & y2002 & & y2003 & y2004 & y2005 & y2006 & y2007 & y2008 & y2009 & y2010 & Row Total \\
\hline 1 & Canon Inc. & 1 & 0 & & 1 & 2 & 3 & 3 & 3 & 2 & 2 & 2 & 3 & 22 \\
\hline 2 & Obic Co., Ltd. & 0 & 2 & & 1 & 1 & 1 & 1 & 3 & 3 & 3 & 4 & 2 & 21 \\
\hline 3 & Kao Corp. & 1 & 1 & & 2 & 2 & 2 & 2 & 2 & 2 & 2 & 2 & 2 & 20 \\
\hline 4 & Aeon Mall Co., Ltd. & 0 & 0 & & 0 & 1 & 2 & 3 & 4 & 2 & 2 & 3 & 3 & 20 \\
\hline 5 & Shimamura Co., Ltd. & 1 & 2 & & 2 & 2 & 2 & 2 & 2 & 0 & 1 & 2 & 4 & 20 \\
\hline 6 & NTN Corp. & 2 & 1 & & 0 & 1 & 2 & 2 & 4 & 3 & 0 & 0 & 1 & 16 \\
\hline 7 & Nachi-Fujikoshi Corp. & 1 & 2 & & 1 & 1 & 2 & 1 & 2 & 1 & 1 & 2 & 2 & 16 \\
\hline 8 & Terumo Corp. & 0 & 1 & & 2 & 1 & 1 & 1 & 0 & 3 & 2 & 3 & 2 & 16 \\
\hline 9 & Mitsubishi Shokuhin Co., Ltd. & 2 & 2 & & 2 & 2 & 2 & 2 & 0 & 2 & 2 & 0 & 0 & 16 \\
\hline 10 & Mitsubishi Logistics Corp. & 0 & 0 & & 2 & 0 & 0 & 1 & 2 & 1 & 4 & 2 & 3 & 15 \\
\hline 11 & Toho Co., Ltd. & 2 & 2 & & 1 & 1 & 1 & 1 & 2 & 3 & 1 & 0 & 1 & 15 \\
\hline 12 & Sekisui House, Ltd. & 1 & 2 & & 1 & 2 & 2 & 2 & 2 & 2 & 0 & 0 & 0 & 14 \\
\hline 13 & Yamazaki Baking Co., Ltd. & 1 & 1 & & 2 & 1 & 2 & 0 & 2 & 1 & 2 & 2 & 0 & 14 \\
\hline 14 & Asahi Group Holdings, Ltd. & 1 & 1 & & 0 & 1 & 1 & 2 & 1 & 2 & 1 & 2 & 2 & 14 \\
\hline 15 & Takeda Pharmaceutical Co., Ltd. & 0 & 1 & & 2 & 2 & 2 & 0 & 1 & 2 & 0 & 2 & 2 & 14 \\
\hline 16 & Toyota Motor Corp. & 0 & 0 & & 0 & 1 & 1 & 2 & 3 & 2 & 1 & 2 & 2 & 14 \\
\hline 17 & Computer Engineering \& Consulting Ltd. & 0 & 0 & & 1 & 2 & 1 & 2 & 3 & 2 & 3 & 0 & 0 & 14 \\
\hline 18 & Kirin Holdings Co., Ltd. & 1 & 2 & & 1 & 2 & 2 & 1 & 0 & 1 & 1 & 1 & 1 & 13 \\
\hline 19 & FamilyMart Co., Ltd. & 1 & 0 & & 1 & 1 & 1 & 1 & 1 & 3 & 2 & 1 & 1 & 13 \\
\hline 20 & Saizeriya Co., Ltd. & 2 & 1 & & 1 & 0 & 1 & 0 & 0 & 1 & 3 & 1 & 3 & 13 \\
\hline 21 & Calpis Co., Ltd. & 2 & 2 & & 1 & 2 & 1 & 2 & 2 & 0 & 0 & 0 & 0 & 12 \\
\hline 22 & Oji Holdings Corp. & 2 & 1 & & 0 & 0 & 0 & 0 & 2 & 1 & 2 & 2 & 2 & 12 \\
\hline 23 & Showa Denko K.K. & 2 & 1 & & 1 & 2 & 0 & 1 & 1 & 2 & 1 & 0 & 1 & 12 \\
\hline 24 & Shin-Etsu Chemical Co., Ltd. & 1 & 1 & & 2 & 1 & 2 & 2 & 1 & 1 & 0 & 0 & 1 & 12 \\
\hline 25 & Yamato Holdings Co., Ltd. & 1 & 1 & & 1 & 1 & 0 & 0 & 0 & 1 & 0 & 4 & 3 & 12 \\
\hline 26 & Oricon Inc. & 0 & 0 & & 2 & 4 & 2 & 1 & 1 & 0 & 0 & 1 & 1 & 12 \\
\hline 27 & Daiwa House Industry Co., Ltd. & 2 & 0 & & 0 & 1 & 1 & 2 & 2 & 1 & 0 & 1 & 1 & 11 \\
\hline 28 & Kaneka Corp. & 1 & 2 & & 2 & 2 & 1 & 2 & 1 & 0 & 0 & 0 & 0 & 11 \\
\hline 29 & Lion Corp. & 1 & 1 & & 2 & 1 & 1 & 1 & 1 & 1 & 1 & 0 & 1 & 11 \\
\hline 30 & KDDI Corp. & 1 & 0 & & 0 & 0 & 0 & 0 & 1 & 2 & 3 & 4 & 0 & 11 \\
\hline 31 & Otsuka Kagu, Ltd. & 1 & 2 & & 2 & 1 & 1 & 4 & 0 & 0 & 0 & 0 & 0 & 11 \\
\hline 32 & Fujifilm Holdings Corp. & 1 & 2 & & 1 & 0 & 0 & 0 & 0 & 1 & 1 & 2 & 2 & 10 \\
\hline 33 & Unicharm Corp. & 1 & 0 & & 1 & 2 & 0 & 1 & 0 & 2 & 1 & 1 & 1 & 10 \\
\hline 34 & Tokyo Tatemono Co., Ltd. & 0 & 2 & & 0 & 1 & 2 & 2 & 0 & 2 & 0 & 1 & 0 & 10 \\
\hline 35 & Sumitomo Realty \& Development Co., Ltd. & 0 & 0 & & 0 & 0 & 1 & 1 & 0 & 3 & 2 & 3 & 0 & 10 \\
\hline 36 & Nomura Research Institute, Ltd. & 0 & 0 & & 0 & 0 & 0 & 0 & 2 & 3 & 2 & 2 & 1 & 10 \\
\hline 37 & LIXIL Group Corp. & 2 & 0 & & 1 & 0 & 0 & 1 & 1 & 2 & 1 & 0 & 2 & 10 \\
\hline 38 & Mandom Corp. & 0 & 0 & & 2 & 1 & 0 & 0 & 2 & 0 & 1 & 2 & 2 & 10 \\
\hline 39 & Daiichikosho Co., Ltd. & 0 & 1 & & 1 & 1 & 0 & 0 & 0 & 0 & 2 & 2 & 3 & 10 \\
\hline
\end{tabular}


Table 5. Firm Characteristics of Serially Previewed vs. Non-Previewed Firms

Firms with preview are the ones that are written up in Nikkei preview articles in year $t$ and $t+1$ during $2000-2010$. Firms without preview are the ones that were never written up in the same period (sample starts in 2001), and matched with firms with preview by market cap. ***, **, and * indicate significance at the $1 \%, 5 \%$, and $10 \%$ levels, respectively.

\begin{tabular}{|c|c|c|c|c|c|c|c|c|c|c|c|c|c|c|c|c|}
\hline \multirow[b]{2}{*}{ Variable } & \multicolumn{6}{|c|}{ Firm-year obs. with preview } & \multicolumn{6}{|c|}{ Firm-year obs. without preview } & \multicolumn{2}{|c|}{ Mean Test (With - W/O) } & \multicolumn{2}{|c|}{ Median Test (With - W/O } \\
\hline & $\mathrm{N}$ & Mean & Std.dev. & Median & Min. & Max. & $\mathrm{N}$ & Mean & Std.dev. & Median & Min. & Max. & Difference & $t$-value & Difference & $Z$-value \\
\hline Market cap. (million yen) & 800 & 648,663 & $1,883,088$ & 162,787 & 1,225 & $27,300,000$ & 800 & 375,108 & 605,340 & 163,586 & 1,227 & $5,452,056$ & 273,556 & $3.91 * * *$ & -799 & 1.00 \\
\hline Proportion of individual investors (\%) & 800 & 29.68 & 19.71 & 24.44 & 1.43 & 97.59 & 800 & 30.08 & 17.56 & 27.16 & 2.37 & 96.07 & -0.40 & -0.43 & -2.72 & -1.54 \\
\hline Proportion of institutional investors (\%) & 800 & 53.31 & 16.89 & 54.09 & 2.12 & 94.41 & 800 & 56.81 & 17.41 & 57.31 & 1.73 & 97.38 & -3.50 & $-4.08 * * *$ & -3.22 & $-4.13 * * * *$ \\
\hline Proportion of foreign investors (\%) & 800 & 16.91 & 12.82 & 15.70 & 0.00 & 68.82 & 800 & 12.86 & 12.78 & 9.07 & 0.00 & 73.30 & 4.05 & $6.33 * * *$ & 6.63 & $7.31 * * *$ \\
\hline Proportion of the special few SHs (\%) & 800 & 45.11 & 18.49 & 42.93 & 0.00 & 92.15 & 800 & 43.01 & 20.01 & 40.37 & 0.00 & 118.07 & 2.10 & $2.18 * *$ & 2.56 & $3.30 * * *$ \\
\hline Floating shares $(\%)$ & 800 & 3.52 & 7.87 & 0.00 & 0.00 & 45.32 & 800 & 4.32 & 9.45 & 0.00 & 0.00 & 60.29 & -0.80 & $-1.83 *$ & 0.00 & -0.47 \\
\hline Turnover & 800 & 0.08 & 0.15 & 0.06 & 0.00 & 3.21 & 800 & 0.07 & 0.10 & 0.04 & 0.00 & 0.99 & 0.01 & $1.97 * *$ & 0.02 & $5.65 * * *$ \\
\hline Listing on TSE 1st section & 800 & 0.81 & 0.39 & 1.00 & 0.00 & 1.00 & 800 & 0.83 & 0.38 & 1.00 & 0.00 & 1.00 & -0.01 & -0.65 & 0.00 & -0.65 \\
\hline
\end{tabular}




\section{Table 6. Regression on Which Firms Are Previewed}

This table reports the regressions coefficients for a probit model. Standard errors (in parentheses) are clustered around firms. The dependent variable is equal to one if the firm-year with preview is the firm-year that has preview articles in that year (t) and year $\mathrm{t}-1$. There are 800 such firm-year observations. Market-cap matched observations of "never previewed" firms are added. The independent variables and their definitions of the independent variables are as follows: the logarithm of market capitalization (in million yen), proportion of individual investors is the number of shares owned by individual investors relative to the total number of shares, proportion of institutional investors is the number of shares owned by financial institutions, financial product dealers, and other corporations relative to the total number of shares, proportion of foreign investors is the number of shares owned by foreign corporations relative to the total number of shares, proportion of the special few shareholders is the number of shares owned by insiders and closely-affiliated firms relative to the total number of shares, floating shares is the number of freely floating shares relative to the total number of shares, turnover is the monthly average of the number of shares traded divided by the total shares outstanding, listed on TSE 1st section equal to one if the firm is listed on the first section of the Tokyo Stock Exchange. The estimation includes industry fixed effects and year fixed effects. The sample includes between 2000 and 2010. ***,**, and * denote coefficient estimates significantly different from zero at the $1 \%, 5 \%$, and $10 \%$ levels (two-sided), respectively.

Dependent variable: Preview coverage $(0$,

1) variable

Variable

\begin{tabular}{|c|c|c|c|c|}
\hline Log(Market cap.) & $\begin{array}{c}0.171 * * * \\
(0.033)\end{array}$ & $\begin{array}{c}0.172 * * * \\
(0.033)\end{array}$ & & \\
\hline Proportion of individual investors (\%) & $\begin{array}{c}0.005^{* *} \\
(0.003)\end{array}$ & & $\begin{array}{c}0.001 \\
(0.002)\end{array}$ & \\
\hline Proportion of institutional investors (\%) & & $\begin{array}{c}-0.005^{* *} \\
(0.003)\end{array}$ & & $\begin{array}{l}-0.001 \\
(0.002)\end{array}$ \\
\hline Proportion of foreign investors $(\%)$ & $\begin{array}{c}0.007 * \\
(0.004)\end{array}$ & $\begin{array}{c}0.002 \\
(0.004)\end{array}$ & $\begin{array}{c}0.015^{* * * *} \\
(0.004)\end{array}$ & $\begin{array}{c}0.014 * * * \\
(0.003)\end{array}$ \\
\hline Proportion of the special few SHs (\%) & $\begin{array}{l}-0.002 \\
(0.002)\end{array}$ & $\begin{array}{c}-0.002 \\
(0.002)\end{array}$ & $\begin{array}{c}-0.004^{*} \\
(0.002)\end{array}$ & $\begin{array}{c}-0.004 * \\
(0.002)\end{array}$ \\
\hline Floating shares $(\%)$ & $\begin{array}{c}0.008 \\
(0.008)\end{array}$ & $\begin{array}{c}0.008 \\
(0.008)\end{array}$ & $\begin{array}{c}0.005 \\
(0.008)\end{array}$ & $\begin{array}{c}0.005 \\
(0.008)\end{array}$ \\
\hline Turnover & $\begin{array}{c}0.076 \\
(0.278)\end{array}$ & $\begin{array}{c}0.076 \\
(0.278)\end{array}$ & $\begin{array}{c}0.158 \\
(0.282)\end{array}$ & $\begin{array}{c}0.157 \\
(0.282)\end{array}$ \\
\hline Listing on TSE 1st section & $\begin{array}{l}-0.008 \\
(0.113)\end{array}$ & $\begin{array}{l}-0.007 \\
(0.113)\end{array}$ & $\begin{array}{c}0.220 * * \\
(0.103)\end{array}$ & $\begin{array}{c}0.222 * * \\
(0.103)\end{array}$ \\
\hline Constant & $\begin{array}{c}-3.705^{* * *} \\
(0.483)\end{array}$ & $\begin{array}{c}-3.186^{* * * *} \\
(0.424)\end{array}$ & $\begin{array}{c}-1.712^{* * *} \\
(0.286)\end{array}$ & $\begin{array}{c}-1.615^{* * *} \\
(0.293)\end{array}$ \\
\hline Industry fixed effect & Yes & Yes & Yes & Yes \\
\hline Year fixed effect & Yes & Yes & Yes & Yes \\
\hline Number of observations & 1,600 & 1,600 & 1,600 & 1,600 \\
\hline Pseudo $R$-squared & 0.240 & 0.240 & 0.227 & 0.228 \\
\hline
\end{tabular}




\section{Table 7. Accuracy of Previews vis-à-vis Management Forecast}

Management Forecast Error $=\mid$ latest management forecast - realized figure|*100/Market cap [million yen] at the end of the month prior to preview release.

Preview Error $=\mid$ preview figure - realized figure|*100/Market cap [million yen] at the end of the month prior to preview release.

\begin{tabular}{lrrrrrrr}
\hline & $\mathrm{N}$ & $\mathrm{Mean}$ & $\mathrm{p} 25$ & Median & $\mathrm{p} 75$ & Min. & Max. \\
\hline Panel A: Management & Forecast Error & Comparing & latest management & forecast & with realized figures \\
Sales & 2,278 & 6.861 & 0.568 & 1.703 & 5.015 & 0.000 & 856.146 \\
Operating Income & 468 & 1.161 & 0.280 & 0.673 & 1.325 & 0.000 & 19.974 \\
Ordinary Iincome & 2,275 & 1.409 & 0.224 & 0.577 & 1.333 & 0.000 & 64.167 \\
Net Income & 2,278 & 1.680 & 0.153 & 0.379 & 0.920 & 0.000 & 232.062 \\
& \multicolumn{7}{c}{} \\
Panel B. Preview Error - Comparing preview numbers with realized figures & & & & \\
Sales & 2,008 & 2.432 & 0.120 & 0.417 & 1.405 & 0.000 & 659.878 \\
Operating Income & 1,356 & 1.048 & 0.042 & 0.139 & 0.413 & 0.000 & 419.900 \\
Ordinary Iincome & 1,432 & 0.405 & 0.038 & 0.123 & 0.341 & 0.000 & 20.514 \\
Net Income & 1,344 & 0.752 & 0.031 & 0.107 & 0.340 & 0.000 & 173.348 \\
\hline
\end{tabular}




\section{Table 8 - 1. Accuracy of [-7, 0] Day Previews - All Previewed Firms}

Management Forecast Error $=\mid$ latest management forecast - realized figure $\left.\right|^{* 100 / M a r k e t ~ c a p ~[m i l l i o n ~ y e n] ~ a t ~ t h e ~ e n d ~ o f ~ t h e ~}$ month prior to preview release.

Preview Error $=\mid$ preview figure - realized figure $\mid * 100 /$ Market cap [million yen] at the end of the month prior to preview release.

\begin{tabular}{lcccccrr} 
& $\mathrm{N}$ & $\mathrm{Mean}$ & $\mathrm{p} 25$ & Median & $\mathrm{p} 75$ & Min. & Max. \\
\hline Panel A: Management Forecast Error - Comparing latest management forecast with realized figures & & \\
Sales & 700 & 5.309 & 0.571 & 1.575 & 4.588 & 0.000 & 146.019 \\
Operating Income & 168 & 1.104 & 0.280 & 0.624 & 1.229 & 0.000 & 16.740 \\
Ordinary Iincome & 700 & 1.150 & 0.189 & 0.504 & 0.991 & 0.000 & 64.167 \\
Net Income & 700 & 1.253 & 0.122 & 0.326 & 0.707 & 0.000 & 136.824 \\
& & & & & & \\
Panel B: Preview Error - Comparing preview numbers & with realized figures & & & & \\
Sales & 624 & 1.434 & 0.066 & 0.256 & 0.818 & 0.000 & 91.019 \\
Operating Income & 394 & 0.915 & 0.022 & 0.077 & 0.219 & 0.000 & 216.110 \\
Ordinary Iincome & 446 & 0.194 & 0.018 & 0.054 & 0.164 & 0.000 & 15.272 \\
Net Income & 400 & 0.565 & 0.019 & 0.044 & 0.136 & 0.000 & 132.492
\end{tabular}

\section{Table $8-2$. Accuracy of $[-7,0]$ Day Previews - "Serially" Previewed Firms}

Only preview articles of serially previewed firms within a week prior to company announcement (i.e., between -7 to 0 ).

\begin{tabular}{|c|c|c|c|c|c|c|c|}
\hline & $\mathrm{N}$ & Mean & $\mathrm{p} 25$ & Median & $\mathrm{p} 75$ & Min. & Max. \\
\hline \multicolumn{8}{|c|}{ Panel A: Management Forecast Error - Comparing latest management forecast with realized figures } \\
\hline Sales & 496 & 4.449 & 0.534 & 1.435 & 4.148 & 0.000 & 134.219 \\
\hline Operating Income & 121 & 0.865 & 0.181 & 0.555 & 1.020 & 0.000 & 8.424 \\
\hline Ordinary Iincome & 496 & 0.842 & 0.172 & 0.425 & 0.788 & 0.000 & 45.608 \\
\hline Net Income & 496 & 0.883 & 0.102 & 0.294 & 0.631 & 0.001 & 127.587 \\
\hline \multicolumn{8}{|c|}{ Panel B: Preview Error - Comparing preview numbers with realized figures } \\
\hline Sales & 457 & 1.272 & 0.065 & 0.242 & 0.742 & 0.000 & 91.019 \\
\hline Operating Income & 299 & 0.204 & 0.021 & 0.069 & 0.195 & 0.000 & 5.822 \\
\hline Ordinary Iincome & 312 & 0.194 & 0.017 & 0.050 & 0.145 & 0.000 & 15.272 \\
\hline Net Income & 300 & 0.555 & 0.016 & 0.037 & 0.112 & 0.000 & 132.492 \\
\hline
\end{tabular}




\section{Table 8 - 3. Accuracy of [-7, 0] Day Previews - "Non-Serially" Previewed Firms}

Only preview articles of non-serially previewed firms within a week prior to company announcement (i.e., between -7 to 0).

\begin{tabular}{|c|c|c|c|c|c|c|c|}
\hline & $\mathrm{N}$ & Mean & $\mathrm{p} 25$ & Median & $\mathrm{p} 75$ & Min. & Max. \\
\hline \multicolumn{8}{|c|}{ Panel A: Management Forecast Error - Comparing latest management forecast with realized figures } \\
\hline Sales & 204 & 7.400 & 0.665 & 1.975 & 5.972 & 0.001 & 146.019 \\
\hline Operating Income & 47 & 1.718 & 0.429 & 0.871 & 1.383 & 0.043 & 16.740 \\
\hline Ordinary Iincome & 204 & 1.899 & 0.281 & 0.663 & 1.562 & 0.000 & 64.167 \\
\hline Net Income & 204 & 2.152 & 0.195 & 0.436 & 1.002 & 0.000 & 136.824 \\
\hline \multicolumn{8}{|c|}{ Panel B: Preview Error - Comparing preview numbers with realized figures } \\
\hline Sales & 167 & 1.877 & 0.070 & 0.319 & 1.093 & 0.000 & 53.330 \\
\hline Operating Income & 95 & 3.153 & 0.024 & 0.104 & 0.407 & 0.000 & 216.110 \\
\hline Ordinary Iincome & 134 & 0.196 & 0.022 & 0.082 & 0.187 & 0.000 & 2.984 \\
\hline Net Income & 100 & 0.594 & 0.029 & 0.093 & 0.254 & 0.000 & 20.333 \\
\hline
\end{tabular}

\section{Table 8 - 4. Tests for Difference between "Serially" and "Non-Serially" Previewed Firms}

Difference in mean Difference in median

\begin{tabular}{lcc}
\hline Panel A: Management Forecast Error - Comparing latest management forecast with realized figures \\
Sales & $-2.951 * * *$ & $-0.540 * *$ \\
Operating Income & $-0.853 * *$ & $-0.315 * * *$ \\
Ordinary Iincome & $-1.058 * * *$ & $-0.238 * * *$ \\
Net Income & $-1.269 * *$ & $-0.142 * * *$ \\
& & \\
Panel B: Preview Error - Comparing preview numbers with realized figures & \\
Sales & -0.606 & -0.077 \\
Operating Income & $-2.949 * *$ & $-0.035 * *$ \\
Ordinary Iincome & -0.002 & $-0.033 * *$ \\
Net Income & -0.039 & $-0.056 * * *$ \\
\hline
\end{tabular}




\section{Table 9. Abnormal Returns, Volatilities, and Volumes, and Spreads}

Cumulative abnormal return is the value of daily abnormal returns, summed over the window indicated. Daily abnormal returns during the event window are defined as the raw return minus the expected return, which is estimated using market model. Abnormal return volatility is the absolute value of daily abnormal returns, summed over the window indicated. Abnormal trading volume is the difference between trading volume and the mean of daily volume for that stock over the pre-preview (or pre-announcement) publication window [270,-21], normalized by the mean volume, then summed over a window. Spread is defined as end of the day quoted (ask-bid)*100/((ask+bid)/2) (averaged over the window indicated). Panel A presents the results of abnormal returns, volatilities, volumes, and spreads response to good news. Panel B presents the results response to bad news. $* * *, * *$, and $*$ indicate significance at the $1 \%, 5 \%$, and $10 \%$ levels, respectively.

\begin{tabular}{|c|c|c|c|c|c|c|c|c|}
\hline \multirow[b]{3}{*}{ Variable } & \multicolumn{6}{|c|}{ Panel A. "Good news" (positive surprise) cases } & \multirow{2}{*}{\multicolumn{2}{|c|}{ Mean test }} \\
\hline & \multicolumn{3}{|c|}{ Preview publication date } & \multicolumn{3}{|c|}{$\begin{array}{l}\text { Matched company announcement } \\
\text { publication date }\end{array}$} & & \\
\hline & $\begin{array}{c}\text { Number of } \\
\text { Observations }\end{array}$ & Mean & $\begin{array}{c}\text { Testing } \\
\text { Mean }=0\end{array}$ & $\begin{array}{l}\text { Number of } \\
\text { Observations }\end{array}$ & Mean & $\begin{array}{c}\text { Testing } \\
\text { Mean }=0\end{array}$ & Difference & $t$-value \\
\hline Cumlative Abnormal Return $(-10,-4)$ & 665 & -0.055 & & 1,238 & -0.181 & & 0.127 & 0.525 \\
\hline Cumlative Abnormal Return $(-3,-1)$ & 669 & 0.875 & **** & 1,253 & 0.460 & **** & 0.415 & $1.799 *$ \\
\hline Cumlative Abnormal Return $(-1,+1)$ & 675 & 0.918 & $* * *$ & 1,256 & 0.480 & $* * *$ & 0.437 & 1.644 \\
\hline Abnormal Return day 0 & 680 & -0.024 & & 1,279 & 0.074 & & -0.098 & -0.704 \\
\hline Abnormal Return Volatility $(-10,-4)$ & 665 & 10.573 & $* * *$ & 1,238 & 9.807 & $* * *$ & 0.766 & $2.141 * *$ \\
\hline Abnormal Return Volatility $(-3,-1)$ & 669 & 5.291 & $* * *$ & 1,253 & 5.372 & $* * *$ & -0.082 & -0.337 \\
\hline Abnormal Return Volatility $(-1,+1)$ & 675 & 5.656 & $* * *$ & 1,256 & 6.020 & $* * *$ & -0.363 & -1.424 \\
\hline Return Volatility day 0 & 680 & 1.795 & $* * *$ & 1,279 & 1.988 & $* * *$ & -0.193 & $-1.836 *$ \\
\hline Abnormal Trading Volume $(-10,-4)$ & 682 & 0.421 & & 1,317 & 1.058 & ** & -0.637 & -0.824 \\
\hline Abnormal Trading Volume $(-3,-1)$ & 682 & -0.010 & & 1,317 & 0.681 & ** & -0.691 & $-1.773 *$ \\
\hline Abnormal Trading Volume $(-1,+1)$ & 682 & 1.137 & **** & 1,317 & 2.077 & **** & -0.940 & -1.584 \\
\hline Abnormal Trading Volume day 0 & 682 & 0.719 & $* * *$ & 1,317 & 1.028 & $* * *$ & -0.309 & -1.021 \\
\hline Averaged spread $(-10,-4)$ & 639 & 0.569 & **** & 1,239 & 0.596 & **** & -0.027 & -0.814 \\
\hline Averaged spread $(-3,-1)$ & 655 & 0.578 & $* * *$ & 1,267 & 0.674 & $* * *$ & -0.097 & $-2.448 * *$ \\
\hline Averaged spread $(-1,+1)$ & 654 & 0.564 & **** & 1,254 & 0.672 & **** & -0.108 & $-2.687 * * *$ \\
\hline Spread day 0 & 668 & 0.578 & $* * *$ & 1,277 & 0.684 & $* * *$ & -0.106 & $-2.239 * *$ \\
\hline
\end{tabular}

\begin{tabular}{|c|c|c|c|c|c|c|c|c|}
\hline \multirow[b]{3}{*}{ Variable } & \multicolumn{6}{|c|}{ Panel B. "Bad news" (negative surprise) cases } & & \\
\hline & \multicolumn{3}{|c|}{ Preview publication date } & \multicolumn{3}{|c|}{$\begin{array}{l}\text { Matched company announcement } \\
\text { publication date }\end{array}$} & \multicolumn{2}{|c|}{ Mean test } \\
\hline & $\begin{array}{c}\text { Number of } \\
\text { Observations }\end{array}$ & Mean & $\begin{array}{c}\text { Testing } \\
\text { Mean }=0\end{array}$ & $\begin{array}{c}\text { Number of } \\
\text { Observations }\end{array}$ & Mean & $\begin{array}{c}\text { Testing } \\
\text { Mean }=0\end{array}$ & Difference & $t$-value \\
\hline Cumlative Abnormal Return $(-10,-4)$ & 444 & -0.072 & & 1,057 & -0.107 & & 0.035 & 0.113 \\
\hline Cumlative Abnormal Return $(-3,-1)$ & 445 & 0.075 & & 1,079 & -0.523 & $* * *$ & 0.599 & $2.196 * *$ \\
\hline Cumlative Abnormal Return $(-1,+1)$ & 447 & -0.049 & & 1,089 & -0.261 & & 0.212 & 0.721 \\
\hline Abnormal Return day 0 & 450 & -0.059 & & 1,098 & 0.028 & & -0.087 & -0.515 \\
\hline Abnormal Return Volatility $(-10,-4)$ & 444 & 11.249 & $* * *$ & 1,057 & 10.980 & $* * *$ & 0.269 & 0.562 \\
\hline Abnormal Return Volatility $(-3,-1)$ & 445 & 5.435 & $* * *$ & 1,079 & 5.573 & $* * *$ & -0.137 & -0.534 \\
\hline Abnormal Return Volatility $(-1,+1)$ & 447 & 5.711 & $* * *$ & 1,089 & 6.208 & $* * *$ & -0.497 & $-1.770 *$ \\
\hline Return Volatility day 0 & 450 & 1.815 & $* * *$ & 1,098 & 2.042 & $* * *$ & -0.227 & $-1.777 *$ \\
\hline Abnormal Trading Volume $(-10,-4)$ & 461 & 0.604 & $*$ & 1,129 & 1.107 & & -0.503 & -0.300 \\
\hline Abnormal Trading Volume $(-3,-1)$ & 461 & -0.034 & & 1,129 & 0.491 & & -0.524 & -0.892 \\
\hline Abnormal Trading Volume $(-1,+1)$ & 461 & 0.889 & $* * *$ & 1,129 & 1.575 & $* * *$ & -0.686 & -0.758 \\
\hline Abnormal Trading Volume day 0 & 461 & 0.559 & $* * *$ & 1,129 & 0.811 & $* * *$ & -0.252 & -0.677 \\
\hline Averaged spread $(-10,-4)$ & 431 & 0.645 & $* * *$ & 1,051 & 0.658 & $* * *$ & -0.013 & -0.295 \\
\hline Averaged spread $(-3,-1)$ & 441 & 0.632 & $* * *$ & 1,080 & 0.729 & $* * *$ & -0.097 & $-1.995 * *$ \\
\hline Averaged spread $(-1,+1)$ & 440 & 0.639 & $* * *$ & 1,070 & 0.716 & $* * *$ & -0.077 & -1.591 \\
\hline Spread day 0 & 450 & 0.634 & $* * *$ & 1,089 & 0.713 & $* * *$ & -0.080 & -1.453 \\
\hline
\end{tabular}

